\title{
Genetic variability, heritability, correlation and path analyses of yield components in traditional rice (Oryza sativa L.) landraces
}

\author{
$\varpi_{\text {Setu Rani Saha }}{ }^{1}$, Lutful Hassan ${ }^{1}$, Md. Ashraful Haque ${ }^{1}$, Mirza Mofazzal Islam² and Md. Rasel ${ }^{1}$ \\ ${ }^{1}$ Department of Genetics and Plant Breeding, Bangladesh Agricultural University, Mymensingh-2202, Bangladesh \\ ${ }^{2}$ Plant Breeding Division, Bangladesh Institute of Nuclear Agriculture, Mymensingh, Bangladesh
}

\begin{tabular}{|c|c|}
\hline ARTICLE INFO OPEN & \\
\hline $\begin{array}{l}\text { Received : } 03 \text { December } 2018 \\
\text { Accepted : } 31 \text { January } 2019 \\
\text { Published: } 31 \text { March } 2019\end{array}$ & \multirow{3}{*}{$\begin{array}{l}\text { The presence of sufficient genetic variability, the knowledge of nature of association among different } \\
\text { characters and relative contribution of different characters to yield is a prerequisite to any breeding } \\
\text { programme. The aim of the present study was to estimate genetic parameters of thirteen yield and yield } \\
\text { attributing traits in } 40 \text { landraces of rice with a view to select better yield attributes in rice. The higher } \\
\text { value of phenotypic co-efficient of variation (PCV) compared to the corresponding genotypic coefficient } \\
\text { of variation (GCV) for all the studied traits indicated that there was an influence of the environment. } \\
\text { Number of unfilled grains per panicle exhibited high estimates of PCV and GCV followed by number of } \\
\text { filled grains per panicle, number of grains per panicle, flag leaf area. High heritability coupled with high } \\
\text { genetic advance was observed in flag leaf area, pollen fertility, number of grains per panicle and number } \\
\text { of filled grains per panicle which reflected that the direct selection of these characters based on phenotypic } \\
\text { expression by simple selection method for yield improvement would be more reliable. Grain yield per } \\
\text { plant showed significant and positive association with days to 50\% flowering, days to maturity, flag leaf } \\
\text { area, number of total tillers per hill, number of effective tillers per hill, pollen fertility, number of grains } \\
\text { per panicle, number of filled grains per panicle indicating selection of these characters for yield } \\
\text { improvement may be rewarding. Both at phenotypic and genotypic level, days to 50\% flowering, flag leaf } \\
\text { area, number of effective tillers per hill, pollen fertility, panicle length, number of grains per panicle and } \\
100 \text { seed weight had direct positive effect on yield per plant indicating their importance during selection in } \\
\text { yield improvement program. Moreover, the information generated from this study, can be exploited in } \\
\text { future rice breeding program. }\end{array}$} \\
\hline & \\
\hline & \\
\hline
\end{tabular}

\section{Introduction}

Rice is the staple food for nearly half of the world's population (Garris et al. 2005; FAO, 2017). It is the third highest worldwide produced crop after maize and sugarcane with annual production of 758.8 million tones (503.6 million tons of milled rice) (FAOSTAT, 2015). Overall production in the Asia has already reached 686.1 million tones (455.3 million tones, milled basis) (FAO, 2017). Bangladesh stands the fourth position in rice production having 52.3 million tones of rice (FAO, 2017). Despite the success in rice production, the country has reached to saturation in the recent years and still faces many challenges to achieve long-term food security. Breaking the existing yield plateau is necessary by developing more promising high yielding varieties.

Bangladesh is a great reservoir of rice with diverse high yielding varieties, landraces and many less known varieties. Landraces are crucial germplasm having diverse source of adaptability genes and incorporation of those genes could ensure optimum grain yield (Mondal et al. 2016). But, high-yielding rice cultivars intruded by green revolution which substituted the traditional rice landraces results in reduced genetic base and increased genetic vulnerability (Tahjib-U1-Arif et al. 2018). So, there is an urgent need to collect, evaluate and utilize these underexplored germplasms.

The information about the extent of several genetic parameters, such as PCV and GCV, broad sense heritability, genetic gain on which the breeding methods are formulated for its further improvement is required for breeding for high yielding crops. Genetic variability forms the basic factor to be considered while making selection. Heritability indicates transmissibility of a character in future generations (Satheeshkumar and Saravanan, 2012). High heritability coupled with high genetic advance is more helpful in forecasting genetic gain (Johnson et al. 1955). Selection based on only yield is often unwise. So it is necessary to know the association between yield and yield components which is determined by correlation analysis (Akhtar et al. 2011). The level of contribution of each yield component trait on yield into direct and indirect effects is determined by path co-efficient analysis (Ahmadizadeh et al. 2011).

The total number of landraces as well as the area planted to landraces in Bangladesh is declining over time (Hossain et al. 2012). If the potentiality of the existing 
high yielding varieties would loss due to biotic and abiotic stresses in the near future, then it will be imperative to utilize landraces as those have the potential to cope up with adversities. Therefore, the present investigation was undertaken to gather some useful information on genetic variability, heritability, genetic advance, character association and path coefficient analysis in a set of 40 rice landraces to be used as suitable breeding materials for developing high yielding rice inbreeds and hybrids.

\section{Materials and Methods}

The present study was conducted at the field laboratory of Plant Breeding Division, Bangladesh Institute of Nuclear Agriculture (BINA), Mymensingh with 40 rice landraces collected from Mymensingh and Sylhet divisions of Bangladesh (listed in supplementary Table 1).

Table 1. List of rice genotypes used in the experiment

\begin{tabular}{|c|c|c|c|c|c|}
\hline $\begin{array}{l}\text { SL. } \\
\text { No. }\end{array}$ & $\begin{array}{c}\text { Name of the } \\
\text { landraces }\end{array}$ & $\begin{array}{l}\text { Source of } \\
\text { collection }\end{array}$ & SL. No. & $\begin{array}{c}\text { Name of the } \\
\text { landraces }\end{array}$ & $\begin{array}{l}\text { Source of } \\
\text { collection }\end{array}$ \\
\hline G1 & Porbotzira & Sunamganj & G21 & Putibirun & Sunamganj \\
\hline G2 & Ailaguta & Sunamganj & G22 & Hashemirri & Netrokona \\
\hline G3 & Birui & Netrokona & $\mathrm{G} 23$ & Guabari & Sunamganj \\
\hline G4 & Chinishail-3 & Netrokona & G24 & Hasa(Kalo) & Sunamganj \\
\hline G5 & Chinishail-2 & Netrokona & G25 & Kalomotashail & Sunamganj \\
\hline G6 & Chinishail-1 & Netrokona & G26 & Mukta & Mymensingh \\
\hline G7 & Notiguarchara & Sunamganj & $\mathrm{G} 27$ & Sadapaijam & Netrokona \\
\hline G8 & Govindo & Netrokona & G28 & Hasa(sada) & Sunamganj \\
\hline G9 & Paijom & Sunamganj & G29 & Biroidhan & Sunamganj \\
\hline G10 & Binnidhan & Mymensingh & G30 & Guarchara & Sunamganj \\
\hline G11 & Faijam & Sunamganj & G31 & Maloti & Sunamganj \\
\hline G12 & Ajanabirun & Sunamganj & G32 & Lalcheng & Sunamganj \\
\hline G13 & Lalpaijam & Netrokona & G33 & Sonajuri & Sunamganj \\
\hline G14 & Moynashail & Sunamganj & G34 & LalKumri & Netrokona \\
\hline G15 & Soragotobirun & Sunamganj & G35 & KaloBiron & Sunamganj \\
\hline G16 & Kutimurabirun & Sunamganj & G36 & Chinigura & Mymensingh \\
\hline G17 & Kashiabinni & Netrokona & G37 & Vedabiron & Sunamganj \\
\hline G18 & Chakloshi & Sunamganj & G38 & Kalojira & Mymensingh \\
\hline G19 & Deshi 32 & Sunamganj & G39 & Boroabji & Netrokona \\
\hline G20 & Chengermuri & Sunamganj & G40 & Chanmoni & Netrokona \\
\hline
\end{tabular}

The seed bed was prepared by raising the soil from the field surface to $5-10 \mathrm{~cm}$ above and then puddling. All the 40 genotypes were sown separately in seedbed on $17^{\text {th }}$ July, 2017. Thirty days old seedlings were transplanted to the main plot with one seedling per hill. Experimental design was randomized complete block design with three replications. Plot size was 1 meter $\times 1$ meter. Row to row and plant to plant distances were maintained as $20 \mathrm{~cm}$ and $15 \mathrm{~cm}$, respectively. Maturity occurs in different genotypes at different times. When the $90 \%$ of the plant population of each plot reached to maturity, then harvesting was done.

Data were recorded on five randomly chosen plants of each genotype for each replication for the selected traits. The traits under consideration were days to $50 \%$ flowering, days to maturity, flag leaf area, plant height, number of total tillers per hill, number of effective tillers per hill, pollen fertility, panicle length, number of grains per panicle, number of filled grains per panicle, number of unfilled grains per panicle, 100 seed weight, and grain yield per plant. The statistical analysis was carried out on the data recorded from 40 rice landraces for yield and its attributing characters.

\section{Statistical analysis}

BASICA software was used to perform correlation coefficient and path co-efficient analysis and different genetic parameters such as genotypic and phenotypic variance, GCV and PCV, heritability, genetic advance and genetic advance as percentage of mean were estimated by using the following formula.

\section{Estimation of genotypic and phenotypic variances}

Genotypic and phenotypic variances were estimated according to the formula given by Johnson et al. (1955).

Genotypic variance, $\sigma_{\mathrm{g}}^{2}=\frac{\mathrm{GMS}-\mathrm{EMS}}{\mathrm{r}}$

Where, GMS = genotypic mean square; EMS = error mean square and $r=$ number of replication

Phenotypic variance, $\sigma_{p}^{2}=\sigma_{g}^{2}+$ EMS

Where, $\sigma_{g}^{2}=$ Genotypic variance

\section{Estimation of heritability}

Heritability in broad sense $\left(\mathrm{h}_{\mathrm{b}}^{2}\right)$ was estimated according to the formula suggested by Johnson et al. (1955).

Heritability, $\mathrm{h}_{\mathrm{b}}^{2}=\frac{\sigma^{2} \mathrm{~g}}{\sigma^{2} \mathrm{p}} \times 100$ 
Where,

$\mathrm{h}_{\mathrm{b}}{ }_{\mathrm{b}}=$ Heritability in broad sense

Heritability was classified as low (below $30 \%$ ), medium (30- 60\%) and high (above 60\%) as suggested by Johnson et al. (1955).

Estimation of genotypic coefficient of variation (GCV) and phenotypic coefficient of variation (PCV) GCV and PCV values were estimated according to the formula given by Burton and De Vane (1953) and Singh and Chaudhury (1985).

Genotypic coefficient of variation,

$$
\mathrm{GCV}=\frac{\sqrt{\sigma_{\mathrm{g}}^{2}}}{\overline{\mathrm{x}}} \times 100
$$

Where, $\bar{x}=$ Population mean

Similarly, Phenotypic coefficient of variation,

$\mathrm{PCV}=\frac{\sqrt{\sigma_{\mathrm{P}}^{2}}}{\overline{\mathrm{x}}} \times 100$

GCV and PCV values were categorized as low $(<10 \%)$, moderate $(10-20 \%)$ and high (>20\%) (Sivasubramanian and Madhavamenon, 1973).

\section{Estimation of genetic advance}

Genetic advance was estimated following the formula given by Johnson et al. (1955).

Genetic advance, $\mathrm{GA}=\mathrm{h}_{\mathrm{b}}^{2} \cdot \mathrm{K} \cdot \sigma_{\mathrm{p}}$

Where, $\mathrm{K}=$ Selection differential, the value of which is

2.06 at $5 \%$ selection intensity

$\sigma_{\mathrm{p}}=$ Phenotypic standard deviation

\section{Estimation of genetic advance as percentage of mean,} GA (\%)

GA (\%) was calculated by the formula of Comstock and Robinson (1952) as follows:

Genetic advance as percentage of mean, GA $(\%)=$ $\frac{\mathrm{GA}}{\overline{\mathrm{X}}} \times 100$

GA $(\%)$ was categorized as low $(0-10 \%)$, moderate (10$20 \%)$ and high $(\geq 20 \%)$ as given by Johnson et al. (1955) and Falconer and Mackay (1996).

\section{Results and Discussion}

\section{Estimation of genetic parameters}

Estimation of genetic parameters, correlation and path analyses helps to explore important characters during the selection for improving yield of rice.

Genotypic variances, phenotypic variances, heritability, genotypic co-efficient of variation (GCV), phenotypic co-efficient of variation (PCV), genetic advance (GA) and genetic advance as percentage of mean, GA (\%) for all the yield contributing traits are shown in Table 2 .
PCV was higher than the corresponding GCV for all the traits indicating that there was an influence of the environment. Similar findings were earlier reported by Bhadru et al. (2012). Highest PCV and GCV were observed for number of unfilled grains per panicle $(43.76 \%$ and $42.54 \%)$ followed by number of filled grains per panicle $(38.63 \%$ and $35.78 \%)$, number of grains per panicle $(35.45 \%$ and $32.31 \%$ ), flag leaf area (30.81\% and $30.42 \%$ ) (Table 2). Bitew (2016) also observed the higher magnitude of PCV and GCV for number of unfilled grains per panicle. The high estimates of PCV and GCV for these traits suggested the possibility of yield improvement through selection of these traits. The traits studied showed moderate to high heritability ranging from $49.7 \%$ to $98.3 \%$. Among the traits studied the highest heritability was recorded by 100 seed weight $(98.3 \%)$ followed by flag leaf area $(97.5 \%)$, number of unfilled grains per panicle $(94.5 \%)$ and pollen fertility $(93.4 \%$ ) (Table 2). The high heritability values of the considered traits in the present study indicated that those were less influenced by the environment and thus help in effective selection of the traits based on the phenotypic expression by adopting simple selection method and suggested the scope of genetic improvement. Similar results for 100 seed weight, number of unfilled grains per panicle and number of effective tillers per plant were earlier recorded by Gour et al. (2017), Sameera et al. (2016) and Sumnath et al. (2017) respectively.

The information on the magnitude of the inheritance of characters from parents to offspring is provided from heritability estimation, while genetic advance is helpful in finding out the actual gain expected under selection. In the present study, genetic advance estimated the highest for the number of the grains per panicle (103.7) followed by number of filled grains per panicle (92.1), flag leaf area (49.8), pollen fertility (31.5) and the lowest for the 100 seed weight (0.99) among the yield contributing traits (Table 2). Sumnath et al. (2017) also found higher genetic advance for number of grains per panicle. The genetic advance as percentage of mean was the highest for the number of unfilled grains per panicle (85.2) and the lowest for days to maturity (4.92) (Table 2). Babu et al. (2012) found the higher genetic advance as percentage of mean for number of unfilled grains per panicle. High heritability along with high genetic advance was observed for the traits, viz., flag leaf area, pollen fertility, number of grains per panicle and number of filled grains per panicle indicated that the characters were mostly governed by additive gene effects (Panse and Sukhatme, 1957) (Table 2). So direct selection of these characters based on phenotypic expression by simple selection method would be effective due to accumulation of more additive genes leading to further improvement. Similar results for number of grains per panicle and number of filled grains per panicle were previously supported by Edukondalu $e t$ al. (2017). 
Table 2. Estimation of genetic parameters for quantitative traits related to yield of forty rice genotypes

\begin{tabular}{clccccccc}
\hline $\begin{array}{c}\text { Sl. } \\
\text { No. }\end{array}$ & \multicolumn{1}{c}{ Characters } & $\begin{array}{c}\text { Phenotypic } \\
\left.\text { variance } \mathbf{(}^{\mathbf{2}} \mathbf{p}\right)\end{array}$ & $\begin{array}{c}\text { Genotypic } \\
\text { variance }\left(\boldsymbol{\delta}^{2} \mathbf{g}\right)\end{array}$ & $\begin{array}{c}\text { PCV } \\
(\boldsymbol{\%})\end{array}$ & $\begin{array}{c}\text { GCV } \\
(\boldsymbol{\%})\end{array}$ & $\begin{array}{c}\text { Heritability } \\
(\boldsymbol{\%})\end{array}$ & $\begin{array}{c}\text { GA } \\
(\boldsymbol{\%} \text { of mean) }\end{array}$ \\
\hline 1 & Days to 50\% flowering & 53.93 & 42.76 & 6.98 & 6.22 & 79.29 & 12.00 & 11.40 \\
2 & Days to maturity & 47.27 & 23.50 & 4.80 & 3.39 & 49.71 & 7.04 & 4.92 \\
3 & Flag leaf area (cm $\left.{ }^{2}\right)$ & 615.52 & 600.20 & 30.81 & 30.42 & 97.51 & 49.84 & 61.88 \\
4 & Plant height (cm) & 134.64 & 119.40 & 9.08 & 8.55 & 88.68 & 21.20 & 16.59 \\
5 & Number of total tillers per hill & 12.10 & 8.34 & 23.80 & 19.76 & 68.93 & 4.94 & 33.79 \\
6 & Number of effective tillers per hill & 9.88 & 9.03 & 24.39 & 23.31 & 91.38 & 5.92 & 45.91 \\
7 & Pollen fertility (\%) & 267.99 & 250.18 & 20.14 & 19.46 & 93.35 & 31.48 & 38.73 \\
8 & Panicle length (cm) & 5.32 & 3.93 & 9.38 & 8.06 & 73.82 & 3.51 & 14.26 \\
9 & Number of grains per panicle & 3667.85 & 3048.03 & 35.45 & 32.31 & 83.10 & 103.68 & 60.68 \\
10 & Number of filled grains per panicle & 2714.54 & 2328.66 & 38.63 & 35.78 & 85.78 & 92.07 & 68.26 \\
11 & Number of unfilled grains per panicle & 250.93 & 237.16 & 43.76 & 42.54 & 94.51 & 30.84 & 85.20 \\
12 & 100 seed weight (g) & 0.24 & 0.23 & 25.97 & 25.75 & 98.32 & 0.99 & 52.60 \\
13 & Grain yield per plant (g) & 30.32 & 25.67 & 30.51 & 28.07 & 84.66 & 9.60 & 53.21 \\
\hline
\end{tabular}

Notes: PCV= Phenotypic coefficient of variation, GCV= Genotypic coefficient of variation, GA= Genetic advance, GA $(\%)=$ Genetic advance as percentage of mean.

Estimation of correlation co-efficient among the traits

Relationships among yield and yield contributing traits were studied through analysis of correlation among them. Phenotypic and genotypic correlation co-efficient among the studied traits of 40 rice genotypes are presented in Table 3. Correlation analysis among the yield and its contributing characters revealed that the genotypic correlation coefficients in most cases were higher than their phenotypic correlation coefficients indicating the association was largely due to genetic reason (Bhattacharyya et al. 2007). The phenotypic correlation coefficients in some cases were higher than their genotypic correlation, which indicates the suppressing effect of the environment that can alter the expression of characters at the phenotypic level. At both genotypic and phenotypic levels, significant positive correlations were observed for yield per plant with days to $50 \%$ flowering, days to maturity, flag leaf area, number of total tillers per hill, number of effective tillers per hill, pollen fertility, number of grains per panicle and number of filled grains per panicle (Table 3). Significant positive correlations at both genotypic and phenotypic levels were recorded for days to $50 \%$ flowering with days to maturity which was supported by Sameera et al. (2016); with plant height, number of filled grains per panicle and yield per plant which were supported by Srijan et al. (2016). Significant positive correlation for days to maturity with yield per plant was previously supported by Aditya and Bhartiya (2013) which is in line with the present study. This might be due to higher accumulation of assimilates as growth duration becomes longer. Significant positive correlations at both genotypic and phenotypic levels were recorded for flag leaf area with yield per plant which was supported by Devi et al. (2017). Higher accumulation of assimilates due to having greater area for photosynthesis might be the reason behind this.

Table 3. Coefficients of phenotypic $\left(r_{p}\right)$ and genotypic $\left(r_{g}\right)$ correlation among different yield components

\begin{tabular}{|c|c|c|c|c|c|c|c|c|c|c|c|c|c|}
\hline Characters & $\begin{array}{c}\text { Correla- } \\
\text { tion }\end{array}$ & DM & $\begin{array}{l}\text { FLA } \\
\left(\mathbf{c m}^{2}\right)\end{array}$ & $\begin{array}{c}\text { PH } \\
(\mathbf{c m})\end{array}$ & TT & ET & $\begin{array}{l}\text { PF } \\
(\%)\end{array}$ & PL (cm) & GPP & FG & UG & $\begin{array}{c}100 \mathrm{SW} \\
(\mathrm{g})\end{array}$ & $\begin{array}{c}\text { YPP } \\
(\mathrm{g})\end{array}$ \\
\hline \multirow{2}{*}{ DF $(50 \%)$} & $\mathrm{r}_{\mathrm{p}}$ & $0.678^{* *}$ & 0.214 & 0.451 ** & 0.248 & 0.305 & 0.261 & -0.026 & 0.241 & $0.331^{*}$ & -0.180 & -0.288 & $0.447 * *$ \\
\hline & $r_{g}$ & $0.683 * *$ & 0.211 & $0.462 * *$ & 0.265 & $0.315^{*}$ & 0.265 & -0.008 & 0.253 & $0.340^{*}$ & -0.174 & -0.294 & $0.466^{* *}$ \\
\hline \multirow{2}{*}{ DM } & $r_{p}$ & & 0.270 & $0.426 * *$ & -0.043 & 0.045 & $0.327^{*}$ & -0.022 & $0.514 * *$ & $0.527 * *$ & 0.198 & -0.239 & $0.441^{* *}$ \\
\hline & $r_{g}$ & & 0.281 & $0.446 * *$ & -0.030 & 0.044 & $0.331^{*}$ & -0.011 & $0.560^{* * *}$ & $0.552^{* * *}$ & 0.216 & -0.238 & $0.477 * *$ \\
\hline \multirow{2}{*}{ FLA $\left(\mathrm{cm}^{2}\right)$} & $\mathrm{r}_{\mathrm{p}}$ & & & -0.051 & 0.152 & 0.178 & 0.060 & -0.042 & $0.356^{*}$ & $0.331 *$ & 0.234 & -0.007 & $0.379^{*}$ \\
\hline & $r_{g}$ & & & -0.050 & 0.151 & 0.177 & 0.060 & -0.046 & $0.360^{*}$ & $0.332 *$ & 0.235 & -0.009 & $0.382 *$ \\
\hline \multirow{2}{*}{ PH (cm) } & $r_{p}$ & & & & -0.049 & 0.015 & 0.149 & $0.487 * *$ & $0.318^{*}$ & $0.394^{*}$ & -0.100 & -0.054 & 0.241 \\
\hline & $r_{g}$ & & & & -0.045 & 0.021 & 0.150 & $0.490 * *$ & $0.316^{*}$ & $0.393^{*}$ & -0.100 & -0.055 & 0.248 \\
\hline \multirow{2}{*}{ TT } & $\mathrm{r}_{\mathrm{p}}$ & & & & & $0.980 * *$ & 0.254 & 0.064 & -0.258 & -0.163 & $-0.404 * *$ & -0.153 & $0.441 * *$ \\
\hline & $r_{g}$ & & & & & $0.972^{* *}$ & 0.250 & 0.061 & -0.271 & -0.168 & $-0.414 * *$ & -0.162 & $0.433^{* *}$ \\
\hline \multirow{2}{*}{ ET } & $r_{p}$ & & & & & & 0.275 & 0.036 & -0.197 & -0.108 & $-0.361 *$ & -0.146 & $0.510^{* * *}$ \\
\hline & $r_{g}$ & & & & & & 0.269 & 0.027 & -0.205 & -0.114 & $-0.364 *$ & -0.148 & $0.502 * *$ \\
\hline \multirow{2}{*}{ PF (\%) } & $r_{p}$ & & & & & & & 0.090 & 0.204 & 0.311 & -0.232 & $-0.394 *$ & $0.382 *$ \\
\hline & $r_{g}$ & & & & & & & 0.090 & 0.203 & 0.306 & -0.229 & $-0.396^{*}$ & $0.385^{*}$ \\
\hline \multirow{2}{*}{ PL (cm) } & $r_{p}$ & & & & & & & & 0.137 & 0.208 & -0.153 & -0.068 & 0.180 \\
\hline & $r_{g}$ & & & & & & & & 0.123 & 0.199 & -0.154 & -0.071 & 0.177 \\
\hline \multirow{2}{*}{ GPP } & $r_{p}$ & & & & & & & & & $0.965 * *$ & $0.577 * *$ & $-0.337 *$ & $0.355^{*}$ \\
\hline & $r_{g}$ & & & & & & & & & $0.941 * *$ & $0.578 * *$ & $-0.340^{*}$ & $0.341 *$ \\
\hline \multirow{2}{*}{ FG } & $r_{p}$ & & & & & & & & & & $0.346^{*}$ & $-0.388^{*}$ & $0.411^{* *}$ \\
\hline & $r_{g}$ & & & & & & & & & & $0.353^{*}$ & $-0.391 *$ & $0.404 * *$ \\
\hline \multirow{2}{*}{ UG } & $r_{p}$ & & & & & & & & & & & 0.008 & -0.012 \\
\hline & $r_{g}$ & & & & & & & & & & & 0.008 & -0.018 \\
\hline \multirow{2}{*}{$100 \mathrm{SW}(\mathrm{g})$} & $r_{p}$ & & & & & & & & & & & & -0.151 \\
\hline & $\mathrm{r}_{\mathrm{g}}$ & & & & & & & & & & & & -0.155 \\
\hline
\end{tabular}

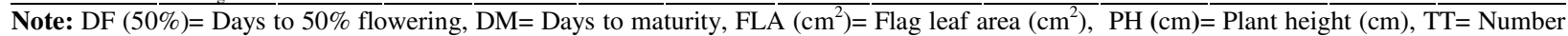
of total tillers per hill, ET= Number of effective tillers per hill, PF $(\%)=$ Pollen fertility $(\%)$, PL $(\mathrm{cm})=$ Panicle length $(\mathrm{cm})$, GPP= Number of grains per panicle, FG= Number of filled grains per panicle, UG= Number of unfilled grains per panicle, $100 \mathrm{SW}(\mathrm{g})=100 \mathrm{Seed}$ weight $(\mathrm{g})$, YPP $(\mathrm{g})=$ Grain yield per plant $(\mathrm{g})$

$*$ and $* *$ indicate significant at $5 \%$ and $1 \%$ level of probability, respectively. 
Plant height had significant positive correlation with panicle length and number of filled grains per panicle which was supported by Srijan et al. (2016). Significant positive correlation for yield per plant with number of total tillers per plant and number of effective tillers per plant was found which were earlier supported by Gour et al. (2017) and Devi et al. (2017), respectively. Significant positive correlation for number of total tillers per plant with number of effective tillers per plant was found. Sameera et al. (2016) also found the same result. Pollen fertility had significant positive correlation with yield per plant because higher percentage of fertile pollen led to higher seed set and ultimately increased yield. Number of grains per panicle and number of filled grains per panicle had significant positive correlation with yield per plant and these results are in consistent with the findings of Kumar et al. (2017). Significant positive correlation of number of grains per panicle with number of filled grains per panicle was also recorded by Vanisree et al. (2013). The negative association of yield per plant with 100 seed weight was found which was supported by Srijan et al. (2016). The number of grains per panicle increased with the decrease in the size of the grains but yield per plant decreased with increasing small grains. The smaller grain size of the majority of the selected landraces may be the reason behind such kind of findings.

Table 4. Partitioning of phenotypic and genotypic correlation coefficients into direct and indirect effects of different yield components

\begin{tabular}{|c|c|c|c|c|c|c|c|c|c|c|c|c|c|c|}
\hline Traits & Correlation & $\begin{array}{c}\text { DF } \\
(50 \%)\end{array}$ & DM & $\begin{array}{l}\text { FLA } \\
\left(\mathrm{cm}^{2}\right)\end{array}$ & PH & $\mathbf{T T}$ & ET & PF (\%) & $\begin{array}{c}\text { PL } \\
(\mathbf{c m})\end{array}$ & GPP & FG & $\mathbf{U G}$ & $\begin{array}{c}100 \\
\mathrm{SW}(\mathrm{g})\end{array}$ & $\begin{array}{c}\text { YPP } \\
(\mathbf{g})\end{array}$ \\
\hline & $\mathbf{r}_{\mathrm{p}}$ & 0.167 & 0.082 & 0.019 & -0.079 & -0.189 & 0.372 & 0.039 & -0.006 & 0.315 & -0.281 & 0.055 & -0.048 & 0.447 ** \\
\hline$(50 \%)$ & $\mathbf{r}_{\mathrm{g}}$ & 0.438 & -0.305 & 0.032 & -0.061 & -0.190 & 0.335 & 0.048 & -0.001 & 0.374 & -0.235 & 0.096 & -0.065 & $0.466^{* *}$ \\
\hline \multirow{2}{*}{ DM } & $\mathbf{r}_{\mathbf{p}}$ & 0.114 & 0.121 & 0.024 & -0.075 & 0.033 & 0.055 & 0.049 & -0.005 & 0.673 & -0.447 & -0.061 & -0.040 & $0.441^{* *}$ \\
\hline & $\mathbf{r}_{\mathrm{g}}$ & 0.299 & -0.446 & 0.042 & -0.058 & 0.022 & 0.047 & 0.060 & -0.001 & 0.828 & -0.381 & 0.118 & -0.053 & $0.477 * *$ \\
\hline \multirow{2}{*}{$\begin{array}{l}\text { FLA } \\
\left(\mathrm{cm}^{2}\right)\end{array}$} & $\mathbf{r}_{p}$ & 0.036 & 0.033 & 0.088 & 0.009 & -0.116 & 0.217 & 0.009 & -0.010 & 0.465 & -0.281 & -0.072 & -0.001 & $0.379 *$ \\
\hline & $\mathbf{r}_{\mathrm{g}}$ & 0.092 & -0.126 & 0.151 & 0.007 & -0.108 & 0.188 & 0.011 & -0.006 & 0.533 & -0.229 & -0.129 & -0.002 & $0.382 *$ \\
\hline \multirow{2}{*}{$\mathrm{PH}$} & $\mathbf{r}_{p}$ & 0.076 & 0.052 & -0.005 & -0.175 & 0.038 & 0.018 & 0.022 & 0.112 & 0.416 & -0.334 & 0.031 & -0.010 & 0.241 \\
\hline & $\mathbf{r}_{\mathrm{g}}$ & 0.202 & -0.199 & -0.008 & -0.131 & 0.032 & 0.022 & 0.027 & 0.063 & 0.467 & -0.271 & 0.055 & -0.012 & 0.248 \\
\hline \multirow{2}{*}{$\mathrm{TT}$} & $\mathbf{r}_{p}$ & 0.042 & -0.005 & 0.013 & 0.009 & -0.765 & 1.19 & 0.038 & 0.015 & -0.338 & 0.138 & 0.124 & -0.026 & $0.441 * *$ \\
\hline & $\mathbf{r}_{\mathrm{g}}$ & 0.116 & 0.013 & 0.023 & 0.006 & -0.717 & 1.03 & 0.046 & 0.008 & -0.400 & 0.116 & 0.227 & -0.036 & $0.433 * *$ \\
\hline \multirow{2}{*}{ ET } & $\mathbf{r}_{\mathrm{p}}$ & 0.051 & 0.005 & 0.016 & -0.003 & -0.750 & 1.22 & 0.041 & 0.008 & -0.258 & 0.092 & 0.110 & -0.024 & $0.510 * *$ \\
\hline & $\mathbf{r}_{\mathrm{g}}$ & 0.138 & -0.019 & 0.027 & -0.003 & -0.697 & 1.06 & 0.049 & 0.004 & -0.303 & 0.079 & 0.199 & -0.033 & $0.502 * *$ \\
\hline \multirow{2}{*}{$\mathrm{PF}(\%)$} & $\mathbf{r}_{\mathbf{p}}$ & 0.044 & 0.039 & 0.005 & -0.026 & -0.195 & 0.336 & 0.148 & 0.021 & 0.267 & -0.264 & 0.071 & -0.066 & $0.382 *$ \\
\hline & $\mathbf{r}_{\mathrm{g}}$ & 0.116 & -0.148 & 0.009 & -0.020 & -0.179 & 0.286 & 0.182 & 0.011 & 0.300 & -0.211 & 0.126 & -0.088 & $0.385^{*}$ \\
\hline \multirow{2}{*}{$\begin{array}{l}\text { PL } \\
(\mathrm{cm})\end{array}$} & $\mathbf{r}_{p}$ & -0.004 & -0.003 & -0.004 & -0.085 & -0.049 & 0.044 & 0.013 & 0.229 & 0.179 & -0.176 & 0.047 & -0.011 & 0.180 \\
\hline & $\mathbf{r}_{\mathrm{g}}$ & -0.004 & 0.005 & -0.007 & -0.063 & -0.044 & 0.029 & 0.016 & 0.131 & 0.182 & -0.137 & 0.085 & -0.016 & 0.177 \\
\hline \multirow{2}{*}{ GPP } & $\mathbf{r}_{\mathrm{p}}$ & 0.040 & 0.062 & 0.031 & -0.056 & 0.198 & -0.241 & 0.030 & 0.031 & 1.31 & -0.818 & -0.176 & -0.056 & $0.355^{*}$ \\
\hline & $\mathbf{r}_{\mathrm{g}}$ & 0.111 & -0.250 & 0.055 & -0.042 & 0.194 & -0.217 & 0.037 & 0.016 & 1.48 & -0.649 & -0.317 & -0.075 & $0.341 *$ \\
\hline \multirow{2}{*}{ FG } & $\mathbf{r}_{p}$ & 0.055 & 0.064 & 0.029 & -0.069 & 0.125 & -0.132 & 0.046 & 0.048 & 1.26 & -0.847 & -0.106 & -0.065 & $0.411^{* *}$ \\
\hline & $\mathbf{r}_{\mathrm{g}}$ & 0.148 & -0.247 & 0.050 & -0.052 & 0.121 & -0.121 & 0.056 & 0.026 & 1.39 & -0.690 & -0.194 & -0.087 & $0.404 * *$ \\
\hline \multirow{2}{*}{ UG } & $\mathbf{r}_{p}$ & -0.030 & 0.024 & 0.021 & 0.018 & 0.309 & -0.441 & -0.035 & -0.035 & 0.755 & -0.293 & -0.306 & 0.001 & -0.012 \\
\hline & $\mathbf{r}_{\mathrm{g}}$ & -0.076 & 0.097 & 0.036 & 0.013 & 0.297 & -0.387 & -0.042 & -0.020 & 0.855 & -0.244 & -0.548 & 0.002 & -0.018 \\
\hline 100 & $\mathbf{r}_{\mathrm{p}}$ & -0.048 & -0.028 & -0.0006 & 0.009 & 0.117 & -0.178 & -0.059 & -0.016 & -0.441 & 0.329 & -0.002 & 0.168 & -0.151 \\
\hline SW (g) & $\mathbf{r}_{\mathrm{g}}$ & -0.129 & 0.106 & -0.001 & 0.007 & 0.116 & -0.157 & -0.072 & -0.009 & -0.503 & 0.269 & -0.004 & 0.221 & -0.155 \\
\hline
\end{tabular}

Note: $\mathrm{DF}(50 \%)=$ Days to $50 \%$ flowering, DM= Days to maturity, FLA $\left(\mathrm{cm}^{2}\right)=$ Flag leaf area $\left(\mathrm{cm}^{2}\right), \mathrm{PH}(\mathrm{cm})=\mathrm{Plant}$ height $(\mathrm{cm}), \mathrm{TT}=\mathrm{Number}$ of total tillers per hill, ET= Number of effective tillers per hill, PF $(\%)=$ Pollen fertility $(\%)$, PL $(\mathrm{cm})=$ Panicle length $(\mathrm{cm})$, GPP= Number of grains per panicle, $\mathrm{FG}=$ Number of filled grains per panicle, $\mathrm{UG}=$ Number of unfilled grains per panicle, $100 \mathrm{SW}(\mathrm{g})=100 \mathrm{Seed}$ weight $(\mathrm{g})$, YPP $(\mathrm{g})=$ Grain yield per plant $(\mathrm{g})$

$*$ and $* *$ indicate significant at $5 \%$ and $1 \%$ level of probability, respectively.

\section{Estimation of path coefficient}

The results of the path coefficient analysis for phenotypic and genotypic correlations are shown in Table 4. At the both phenotypic and genotypic levels, days to $50 \%$ flowering, flag leaf area, number of effective tillers per hill, pollen fertility, panicle length, number of grains per panicle and 100 seed weight had direct positive effect on yield per plant with number of grains per panicle given the highest contribution on yield per plant (Table 4). Similar findings were reported for days to $50 \%$ flowering and panicle length by Seyoum et al. (2012); for number of effective tillers per hill and 100 seed weight by Devi et al. (2017). Direct positive effect of the aforesaid characters on grain yield indicated that selection of these traits is directly helpful for the improvement of yield. The highest positive indirect effect on grain yield per plant was recorded by number of filled grains per panicle followed by number of total tillers per hill, number of unfilled grains per panicle, days to maturity, flag leaf area and plant height at both phenotypic and genotypic levels (Table 4). High direct effect along with positive and high indirect effects through other traits provides a better chance for a character to be selected in breeding programs (Gour et al. 2017). In this study, plant height, number of total tillers per hill, number of filled grains per panicle, number of unfilled grains per panicle had direct negative effect on yield per plant (Table 4). Negative direct effect of plant height on grain yield per plant indicated that tallness in rice lowers the yield due to high accumulation of photosynthates in vegetative parts as compared to reproductive parts (i.e. seed formation and grain filling) 
and lodging susceptibility (Zahid et al. 2006). The yield per plant of the selected landraces can be increased with reduction in plant height. A significant positive correlation was present between number of filled grains per panicle with grain yield per plant but its direct effect is negative (Table 4). Therefore, the indirect effects appeared to be the cause of correlation. This character influenced grain yield per plant by its highest indirect positive effects. The same result was recently reported by Kumar et al. (2017). But Sarwar et al. (2015) and Hairmansis et al. (2011) found positive direct effect of filled grains per panicle on yield per plant. The weight of 100 seeds showed direct positive effect on grain yield per plant but had negative association with grain yield per plant at both genotypic and phenotypic levels (Table 4). The direct effect of 100 seed weight was seemed to be neutralized by its considerable indirect negative effects via days to $50 \%$ flowering, flag leaf area, number of effective tillers per hill, pollen fertility, panicle length, number of grains per panicle and number of unfilled grains per panicle. Similar result was also supported by Kumar et al. (2017). If the correlation of a character with yield is negative but its direct effect is positive and high, a restricted simultaneous selection model should be followed, i.e. restrictions are to be imposed to nullify the unwanted indirect effects in order to make use of the direct effect (Rashid et al. 2010).

The residual effect determines how best the causal factors account for the variability of the resultant factor, the yield per plant. In the present study the residual effect was 0.40 and 0.47 at phenotypic and genotypic level, respectively (Table 4). Residual effect (0.40) indicated that the characters which were selected in this study contributed $60 \%$ to the yield. The reason seems to be very low and non-significant correlation of some traits with yield. Besides, some other factors like sampling error, personal error and geographical position which have not been considered here need to be included in this analysis to account fully for the variation in yield.

\section{Conclusion}

In a nutshell, the studied landraces of rice has the potential for incorporating certain important and valuable traits. Estimation of genetic parameters, correlation analysis and path coefficient analysis revealed that the flag leaf area, number of effective tillers per hill, pollen fertility and number of grains per panicle were the most reliable traits for yield improvement in rice. So the utmost importance should be given to these characters during the selection for yield improvement in rice.

\section{Acknowledgments}

Plant Breeding Division, Bangladesh Institute of Nuclear Agriculture (BINA), Mymensingh is gratefully acknowledged for the funding support and making this research study feasible.

\section{References}

Aditya, J.P. and Bhartiya, A. 2013. Genetic variability, correlation and path analysis for quantitative characters in rainfed upland rice of Uttarakh and Hills. Journal of Rice Research, 6(2): 24-34.

Ahmadizadeh, M., Nori, A., Shahbazi, H. and Aharizad, S. 2011. Correlated response of morpho-physiological traits of grain yield in durum wheat under normal irrigation and drought stress conditions in greenhouse. African Journal of Biotechnology, 10(85): 19771-19779.

Akhtar, N., Nazir, M.F., Rabnawaz, A., Mahmood, T., Safdar, M.E., Asif, M. and Rehman, A. 2011. Estimation of heritability, correlation and path coefficient analysis in fine grain rice (Oryza sativa L.). Journal of Animal and Plant Science, 21(4): 660-664.

Babu, V.R., Shreya, K., Dangi, K.S., Usharani, G. and Nagesh, P. 2012. Genetic variability studies for qualitative and quantitative traits in popular rice (Oryza sativa L.) hybrids of India. International Journal of Scientific and Research Publications, 2(6): 1-5.

Bhadru, D., Rao, V.T., Mohan, Y.C. and Bharathi, D. 2012. Genetic variability and diversity studies in yield and its component traits in rice (Oryza sativa L.). SABRAO Journal of Breeding and Genetics, 44(1): 129-137.

Bhattacharyya, R., Roy, B., Kabi, M.C. and Basu, A.K. 2007. Character association and path analysis of seed yield and its attributes in rice as affected by bio-inoculums under tropical environment. Tropical Agricultural Research Extension, 10: 23-28. https://doi.org/10.4038/tare.v10i0.1867

Bitew, J.M. 2016. Estimation of genetic parameters, heritability and genetic advance for yield related traits in upland rice (Oryza sativa L. and Oryza glaberrima Steud.) genotypes in northwestern Ethiopia. World Scientific News, 47(2): 340350 .

Burton, G.W. and De Vane, E.H. 1953. Estimating heritability in tall fesscusce from replicated clone natural materials. Journal of Agronomy, 45: 171-181.

Comstock, R.E. and Robinson, H.F. 1952. Genetic parameters, their estimate and significance. Proceedings of the 6th International Grassland Congress, 1: 284-291.

Devi, K.R., Chandra, B.S., Lingaiah, N., Hari, Y. and Venkanna, V. 2017. Analysis of variability, correlation and path coefficient studies for yield and quality traits in rice (Oryza Sativa L.). Agricultural Science Digest, 37(1): 1-9.

Edukondalu, B., Reddy, V.R., Rani, T.S., Kumari, C.A. and Soundharya, B. 2017. Studies on variability, heritability, correlation and path analysis for yield, yield attributes in rice (Oryza sativa L.). International Journal of Current Microbiology and Applied Sciences, 6(10): 2369-2376. https://doi.org/10.20546/ijcmas.2017.610.279

Falconer, D.S. and Mackay, F.C. 1996. Introduction to quantitative genetics. Longman, New York. pp. 464.

FAO. 2017. Rice Market Monitor/July 2017. pp 3-4. (http://www.fao.org/fileadmin/templates/est/COMM_MAR KETS_MONITORING/Rice/Images/RMM/RMM-Jul17).

FAOSTAT. 2015. World's crop production. Food and agricultural organization.

Garris, A.J., Tai, T.H., Coburn, J., Kresovich, S. and McCouch, S. 2005. Genetic structure and diversity in Oryza sativa L. Genetics, 169: 1631-1638. https://doi.org/10.1534/genetics.104.035642

Gour, L., Koutu, G.K., Singh, S.K., Patel, D.D., Shrivastava, A. and Singh, Y. 2017. Genetic variability, correlation and path analyses for selection in elite breeding materials of rice (Oryza sativa L.) genotypes in Madhya Pradesh. The Pharma Innovation Journal, 6(11): 693-696.

Hairmansis, A., Kustianto, B. and Suwarno, S. 2011. Correlation analysis of agronomic characters and grain yield of rice for tidal swamp areas. Indonesian Journal of Agricultural Science, 11(1): 11-15. https://doi.org/10.21082/ijas.v11n1.2010.11-15

Hossain, M., Jaim, W.M.H., Paris, T.R. and Hardy, B. 2012. Adoption and diffusion of modern rice varieties in Bangladesh and 
eastern India. Los Banos, Philippines. International Rice Research Institute.

Johnson, H.W., Robinson, H.F. and Comstock, R.E. 1955. Estimates of genetic and environmental variability in soybeans. Journal of Agronomy, 47: 314-318. https://doi.org/10.2134/agronj1955.00021962004700070009x

Kumar, S., Bhuvaneswari, S., Devi, E.L., Sharma, S.K., Ansari, M.A., Singh, I.M., Singh, Y.R. and Prakash, N. 2017. Estimation of genetic variability, correlation and path analysis in short duration rice genotypes of Manipur. Journal of Agri Search, 4(2): 112-118. https://doi.org/10.21921/jas.v4i2.7782

Mondal, S., Rutkoski, J.E., Velu, G., Singh, P.K., Crespo-Herrera, L.A., Guzman, C., Bhavani, S., Lan, C., He, X. and Singh, R.P. 2016. Harnessing diversity in wheat to enhance grain yield, climate resilience, disease and insect pest resistance and nutrition through conventional and modern breeding approaches. Frontiers in Plant Science, 7: 991. https://doi.org/10.3389/fpls.2016.00991

Panse, V.G. and Sukhatme, P.V. 1957. Genetics and quantitative characters in relation to plant breeding. Indian Journal of Genetics, 17: 312-328.

Rashid, M.H., Parveen, S. and Bhuiyan, M.S.R. 2010. Genetic variability, correlation and path coefficient analysis in nineteen Brassica rapa germplasm. Journal of Sher-eBangla Agricultural University, 4(1): 84-89.

Sameera, S., Srinivas, T., Rajesh, A.P., Jayalakshmi, V. and Nirmala, P.J. 2016. Variability and path co-efficient for yield and yield components in rice. Bangladesh Journal of Agricultural Research, 41(2): 259-271. https://doi.org/10.3329/bjar.v41i2.28229

Sarwar, G., Harun-Ur-Rashid, M., Parveen, S. and Hossain, M.S 2015. Correlation and path coefficient analysis for agromorphological important traits in Aman rice genotypes (Oryza sativa L.). Advances in Bioresearch, 6(4): 40-47.

Satheeshkumar, P. and Saravanan, K. 2012. Genetic variability, correlation and path analysis in rice (Oryza Sativa L.). International Journal of Current Research, 4: 82-85.
Seyoum, M., Alamerew, S. and Bantte, K. 2012. Genetic variability, heritability, correlation coefficient and path analysis for yield and yield related traits in upland rice (Oryza sativa L.). Journal of Plant Sciences, 7(1): 13-22. https://doi.org/10.3923/jps.2012.13.22

Singh, R.K. and Chaudhury, B.D. 1985. Biometrical method in quantitative genetic analysis. Kalyani Publishers, Ludhiana, New Delhi, India. pp. 318.

Sivasubramanian, S. and Madhavamenon, P. 1973. Genotypic and phenotypic variability in rice. Madras Agricultural Journal, 60: 1093-1096.

Srijan, A., Kumar, S.S., Raju, C.D. and Jagadeeshwar, R. 2016. Character association and path coefficient analysis for grain yield of parents and hybrids in rice (Oryza sativa L.). Journal of Applied and Natural Science, 8(1): 167-172. https://doi.org/10.31018/jans.v8i1.768

Sumanth, V., Suresh, B.G., Ram, B.J. and Srujana, G. 2017. Estimation of genetic variability, heritability and genetic advance for grain yield components in rice (Oryza sativa L.). Journal of Pharmacognosy and Phytochemistry, 6(4): 1437-1439.

Tahjib-Ul-Arif, M., Sayed, M.A., Islam, M.M., Siddiqui, M.N., Begum, S.N. and Hossain, M.A. 2018.Screening of rice landraces (Oryza sativa L.) for seedling stage salinity tolerance using morpho-physiological and molecular markers. Acta Physiologiae Plantarum, 40: 70. https://doi.org/10.1007/s11738-018-2645-4

Vanisree, S., Swapna, K., Raju, C.D., Raju, C.S. and Sreedhar, M. 2013. Genetic variability and selection criteria in rice. Journal of Biological \& Scientific Opinion, 1(4): 341-346. https://doi.org/10.7897/2321-6328.01413

Zahid, M.A., Akhtar, M., Sabir, M., Manzoor, Z. and Awan, T.H. 2006. Correlation and path analysis studies of yield and economic traits in Basmati rice (Oryza sativa L.). Asian Journal of Plant Science, 5: 643-645. https://doi.org/10.3923/ajps.2006.643.645 